\title{
Avoiding Broken Noses
}

How "Pragmatic" was the Philosophy of Thomas Reid?1

\section{Adrian Sackson}

\section{(2) OpenEdition}

\section{Journals}

Electronic version

URL: http://journals.openedition.org/ejpap/1065

DOI: 10.4000/ejpap.1065

ISSN: 2036-4091

Publisher

Associazione Pragma

\section{Electronic reference}

Adrian Sackson, « Avoiding Broken Noses », European Journal of Pragmatism and American Philosophy [Online], VI-2 | 2014, Online since 24 December 2014, connection on 23 April 2019. URL : http:// journals.openedition.org/ejpap/1065; DOI : 10.4000/ejpap.1065

This text was automatically generated on 23 April 2019

\section{(c) (1) $\odot$}

Author retains copyright and grants the European Journal of Pragmatism and American Philosophy right of first publication with the work simultaneously licensed under a Creative Commons AttributionNonCommercial-NoDerivatives 4.0 International License. 


\title{
Avoiding Broken Noses
}

How "Pragmatic" was the Philosophy of Thomas Reid?1

\author{
Adrian Sackson
}

\section{AUTHOR'S NOTE}

My thanks to the reviewers for their very helpful comments, and to the NYU Global Research Institute in Tel Aviv, which enabled me to complete the final version of this article.

1 The intellectual affinity between Thomas Reid, on one hand, and American pragmatists such as Charles Sanders Peirce, William James, and John Dewey, on the other, has been noted by several scholars. Indeed, Peirce himself professed an admiration for Reid and referred to his own version of Pragmatism as entailing what he called "Critical Commonsensism" (Peirce 1966: 204-15). In recent times, a number of scholars - chiefly Baumann, Magnus, and Lundestad - have investigated the pragmatist elements in Reid's thought. Each has identified important ways in which Reid prefigured central themes in American pragmatist thought, though none has gone so far as to label Reid himself a pragmatist.

of course, a discussion about what constitute the "essential" features of Pragmatism would be meaningless, since there are significant differences among the classic American pragmatist thinkers themselves, and any attempt to define the boundaries of a school of thought is subject to arbitrary choices. Nevertheless, I believe that it can be shown that Reid's approach to epistemic normativity and the justification of belief incorporates a comprehensive range of pragmatist elements. He is, I claim, closer to the tradition of American Pragmatism than has been suggested previously, and the differences between Reid and any given pragmatist thinker may be no greater than those between 'undisputed' pragmatists, such as Peirce and James.

In this paper, I hope to show the extent of the similarities between Reid and some of the early American pragmatists. In light of these parallels, the term "pragmatist" may, in my opinion, be helpful for categorising Reid's thought. My central claim, however, is not merely a terminological one: Rather, I hope to demonstrate the deep and broad affinity 
between Reid's Common Sense philosophy and major trends in American Pragmatism, by shedding light on a number of distinct and central shared features - some of which have been pointed out previously, and others that have not. In the first section of the paper, I will discuss analyses of Reid's relationship with Pragmatism by Baumann, Magnus, and Lundestad. I will examine the debate between Baumann and Magnus regarding which aspects of Reid's thought constitute its (proto-) pragmatist elements. I will also explore Lundestad's argument that Pragmatism can "save" Reid's Common Sense philosophy from its deepest flaw. My central interest here will be to identify important similarities between Reid and the American pragmatists which emerge from these discussions.

In the second section, I will present a more thoroughgoing analysis of the similarities highlighted by Baumann, Magnus, and Lundestad, as well as additional features which they do not discuss. As I hope to show, Reid is even closer to the central currents of American Pragmatism than any of these scholars has suggested. Of course, Reid belonged to a different time and place than the American pragmatist thinkers. Nevertheless, the intellectual affinity between them is both deep and broad sufficiently so, in my opinion, to justify the characterisation of Reid as belonging, in important respects, to the diverse and rich school of thought known as Pragmatism.

\section{A Proto-Pragmatist? Baumann, Magnus, and Lundestad}

5 There is one important passage by Reid which Baumann, Magnus, and Lundestad all cite in their respective discussions of Reid's affinity with Pragmatism - though they interpret it differently. This passage appears in the context of Reid's discussion of three reasons that he does not accept sceptics' arguments against trust in human perception. Reid's second reason is highly relevant for our purposes, so I present it here:

I think it would not be prudent to throw off this belief [in perception], if it were in my power...I resolve not to believe my senses. I break my nose against a post that comes in my way; I step into a dirty kennel; and, after twenty such wise rational actions, I am taken up and clapped into a mad-house. Now, I confess I would rather make one of the credulous fools whom Nature imposes upon, than of those wise and rational philosophers who resolve to withhold assent at all this expense. (Reid 1983: 85-6)

6 We see here a decidedly pragmatic justification for trusting perception: Doing so is practically beneficial to the individual. Since I gain from my trust in perception and suffer from distrust in it, I should affirm that perception is reliable. Even if nature is actually "imposing" on me, this is irrelevant, since my interactions with the "incorrectly" perceived world around me can still cause me very tangible suffering -for example, in the form of a broken nose. Reid's argument continues with an additional claim:

If a man pretends to be a sceptic with regard to the informations of sense, and yet prudently keeps out of harm's way as other men do, he must excuse my suspicion, that he either acts the hypocrite, or imposes upon himself. For, if the scale of his belief were so evenly poised as to lean no more to one side than to the contrary, it is impossible that his actions could be directed by any rules of common prudence. (Reid 1983: 86)

7 This second part of the argument is directed against the actions of a "so-called" sceptic. According to Reid, an individual's actions betray her true beliefs. Thus, a "sceptic" who claims to have no trust in human perception, but who nevertheless behaves in a way that 
enables her to avoid walking into kennels and breaking her nose, arouses Reid's suspicion that she is not truly a sceptic. With these passages in mind, let us examine the claims made by Baumann and Magnus.

In a 1999 article, Baumann claims that Reid's Common Sense philosophy involves a rejection of the alternative between Scepticism and Dogmatism. Since the principles of common sense are, for Reid, first truths, they are not and cannot be justified using reason. This opens the door to Scepticism, on one hand, and Dogmatism, on the other. The Common Sense philosopher refuses "to carry the burden of proof at all: arguing only for the thesis that we cannot argue for the principles of common sense," Baumann writes. As such, he "moves close to a bad dogmatist neighbourhood and risks becoming a dogmatist himself who just asserts the truth of his first principles without arguing for it" (Baumann 1999: 51). On the other hand, rather than accepting these first truths without justification, a philosopher might choose "not to make any truth and knowledge claims concerning the principles of common sense and thus to avoid any further justificatory burdens" (Baumann 1999: 51). According to Baumann, this sceptical option - which Reid identifies with Hume - is "the common sense philosopher's hell." Baumann argues that Reid, in his desire to reject both Dogmatism and Scepticism, charts a third way which "hints" at a pragmatist solution (Baumann 1999: 51).

9 How does Reid resolve this dilemma? According to Baumann, he points in the direction of a solution by attempting - at least to some extent - to shift the discussion away from justification of our view of the world and toward description of it. Baumann cites Reid himself, who claims that most people are shaped by nature and conditioning: "Most men continue all their days to be just what Nature and human education made them. Their manners, their opinions, their virtues, and their vices, are all got by habit, imitation, and instruction; and reason has little or no share in forming them" (Reid 2005: 201). Baumann describes the significance of this move as follows:

We cannot justify the principles of knowledge and we do not even need to justify them. This gives Reid's naturalism a pragmatist twist. The search for a theoretical justification of the principles of common sense does not even make sense. We are asking the wrong question if we want to know reasons for first principles. To ask for reasons here is to fundamentally misunderstand what a first principle is. This is what Reid says, except that he is not willing to stop talking about the truth and knowledge claims that come with the principles of common sense. To give up this recourse to truth and knowledge would mean to fully become a pragmatist.

Even if we cannot give justifying reasons for our principles of knowledge, we can give a totally different kind of justification: a pragmatic justification. The principles of common sense enable us to build theories which guide our actions and let us attain goals. Insofar as they fulfill this function, they are justified and there is no place for a different kind of justification, no need to talk about truth or knowledge [...]. To be sure, Reid does not make this last step. He does not really talk about pragmatic justification. But he is very close to this kind of pragmatism and I wanted to show here that he is much closer to pragmatism than one might think at first hand. (Baumann 1999: 53)

10 According to Baumann, then, Reid is not a pragmatist, though one "might even regard him as one of the grandfathers of pragmatism" (Baumann 1999: 53). Reid does, however, chart out the beginnings of a route which avoids the Scepticism/Dogmatism dichotomy through the claim that it does not make sense to look for justifications for the principles of common sense, and that, therefore, these principles ought to be accepted on the grounds that they assist us in attaining our goals. Reid cannot, according to Baumann, be described 
as a pragmatist thinker, because he still talks about truth and knowledge (rather than pragmatic justification alone); and because, unlike Peirce and other American pragmatists, he does not believe that "the principles of common sense are open to revision" (Baumann 1999: 53). This last claim, as we shall see later, can be questioned.

11 In a response to Baumann's 1999 article, Magnus disagrees with Baumann's claim that Reid does not talk about pragmatic justification. In fact, Magnus argues, Reid does "make a kind of pragmatic move, one that is importantly more subtle" than that suggested by Baumann (Magnus 2004: 71). This move is found in the latter part of the "broken nose" passage cited above. Magnus contends that the crux of this argument against Scepticism goes further than simply claiming that belief in perceptions "gets us what we want":

Reid's argument is more subtle than this. He insists that sincere scepticism would undercut practical engagement with the world and thus that the so-called sceptic betrays a belief in the real world by managing their affairs just as common folk do...We might call this an argument from practical commitment. If sceptics navigate the world in the way you or I do, they already do believe in an external world [...]. Sceptics are already engaged in certain practices that show that they already do accept common sense, whatever their verbal protestations to the contrary. (Magnus 2004: 71)

12 Magnus's understanding of Reid's affinity with Pragmatism is thus more concerned with Reid's argument against Scepticism than it is with his alternative to it. Where Baumann understood Reid to be offering the kernel of a pragmatist "third way" - a justificatory method that is neither dogmatist nor sceptical, Magnus sees Reid as employing an argument against sceptics that parallels the logic of the "pragmatic maxim," articulated by Peirce as follows: "Consider what effects that might conceivably have practical bearing you conceive the object of your conception to have. Then your conception of those effects is the whole of your conception of the object" (Peirce 1966: 192). In "What Pragmatism Means," James elaborates on this principle:

The pragmatic method in such cases is to try to interpret each notion by tracing its respective practical consequences. What difference would it practically make to any one if this notion rather than that notion were true? If no practical difference whatever can be traced, then the alternatives mean practically the same thing, and all dispute is idle. Whenever a dispute is serious, we ought to be able to show some practical differences that must follow from one side or the other's being right. (James 1977: 377)

13 In "How to Make Our Ideas Clear," Peirce offers a similar account of what it means for beliefs to be distinct:

The essence of belief is the establishment of a habit; and different beliefs are distinguished by the different modes of action to which they give rise. If beliefs do not differ in this respect, if they appease the same doubt by producing the same rule of action, then no mere differences in the manner of consciousness of them can make them different beliefs, any more than playing a tune in different keys is playing different tunes. (Peirce 1966: 121)

14 According to Magnus, then, a form of argument akin to Peirce's 'pragmatic maxim' is employed by Reid against Hume and other sceptics: If there is no practical difference that follows from adopting Scepticism, then there is no meaningful difference between it and non-Scepticism. As Magnus puts it, "Reid applies the pragmatic method to show that the would-be sceptic tacitly gives the lie to his scepticism by skillfully navigating the world" (Magnus 2004: 72). 
In a 2004 reply to Magnus, Baumann clarifies his own claim and responds to Magnus's presentation of the pragmatist elements in Reid's thought. According to Baumann, Magnus's ascription to Reid of the "argument from practical commitment" is correct but uncontroversial. "Do Magnus and I disagree at all? I am not so sure. I don't doubt that what he calls the 'argument from practical commitment' can be attributed to Reid. On this point we certainly do not disagree. The problem is that this alone, without further explanations, doesn't cut much ice in the debate against the sceptic; even the sceptic can agree with it" (Baumann 2004: 76). It seems to me, however, that Baumann has misunderstood the details of Magnus's argument. The claim to which Baumann is assenting (and which he believes Magnus to be making) is that even declared "sceptics" do not adopt their own ideas as practical principles by which they live their lives. Regarding this claim, Baumann writes: "I do not have any objections to this - nobody has. Even Reid's arch-sceptic Hume wholeheartedly agrees: Nobody can live scepticism in everyday life" (Baumann 2004: 76).

If I have understood Magnus correctly, however, this is not the (only) claim that he is making. Rather, he is arguing, as I explained above, that Reid employs reasoning similar to that of Peirce's "pragmatic maxim" - namely, that the difference between concepts is to be found in their practical effects. If there is no difference in outcome, there is no justification for speaking of a difference in the concepts. To this claim, contra Baumann, many would indeed object.

Aside from Baumann's (mis)understanding of Magnus, he also offers an elaboration of the (proto-)Pragmatism which he himself sees at work in Reid. Like Magnus, Baumann now points to Reid's "broken nose" passage. In this passage,

Baumann claims, Reid is making an argument against Scepticism that is reminiscent of Reichenbach's pragmatic justification of induction, or of Pascal's Wager (albeit without Pascal's doctrinal assumptions):

If the external world exists, then it is a more dangerous place for sceptics than for the followers of common sense. Given that we prefer not to break our noses, common sense is better off - given the existence of the world - than scepticism. If the external world does not exist, then there is no difference between the two positions in terms of practical outcomes. Hence, common sense "dominates" scepticism: The outcomes of common sense are always at least as good as those of scepticism and they are better under at least one circumstance (the external world exists). The solution to our problem is clear: We should go for common sense and the belief in the existence of the external world. This is a pragmatic and not an epistemic justification of a principle of common sense. It leaves the epistemic status of such principles (as to truth, justification, etc.) open; the outcomes are defined in practical rather than epistemic terms. However, it still gives us a reason in favour of common sense, namely a practical one. (Baumann 2004: 75; italics mine)

From our examination of the discussion between Baumann and Magnus, we are thus far able to identify at least three important elements of Reid's thought that bear similarity to American Pragmatism: (1) Reid's opposition to both Scepticism and Dogmatism; (2) The "argument from practical commitment" (though I believe Baumann misunderstood what Magnus means by this, both readings have important pragmatist parallels); and (3) Baumann's "Pascalian"/"Reichenbachian" reading of Reid's “broken nose" passage.

Finally, we come to Lundestad, who has discussed the affinity between Reid and American Pragmatism in two separate articles (Lundestad 2006; 2008). Lundestad offers separate but interconnected theses in these two articles: In the first, he claims that Reid's Common 
Sense philosophy contains an important insight - namely, that the demands of sceptics for justification of all beliefs cannot be met, and that "there are beliefs, such as our belief in an external reality, which we are not in a position to doubt, and which must therefore be taken for granted, even if we are not in position to justify them" (Lundestad 2006: 129). This fundamental insight, however, is undermined by the stalemate in which Reid is left against the sceptics: "While Reid may rightfully claim that the skeptic doesn't really doubt the existence of external reality, the skeptic may, with just as much right, claim that Reid has missed the point, namely that our belief in external reality isn't justified" (Lundestad 2006: 132). According to Lundestad, Common Sense philosophy is "protopragmatic" in the sense that Pragmatism can liberate it from the problematic premises which lead it into this stalemate. In his second article, Lundestad argues that Scepticism and Common Sense philosophy can be seen as two horns of a dilemma that can be resolved using a pragmatic approach. When "one performs the pragmatic shift from theory to practice, viewing our primary way of relating to the world as being practical rather than theoretical," a resolution of the dilemma becomes possible (Lundestad 2008: 184-5).

21 My central concern here is an interpretive one, and, as such, I will not engage here with Lundestad's claims regarding the possibility of Pragmatism "liberating" Reid's philosophical approach from its unacceptable premises. Rather, I wish to point to the additional pragmatist elements of Reid's thought which emerge from Lundestad's study. One such similarity is: (4) the distinction between real and apparent doubt. Lundestad describes this tendency in Reid as follows:

What Reid has actually done - even though he never says so explicitly - is to introduce a distinction between real and apparent doubt. The first person to draw explicit attention to such a distinction was, as we know, Charles Sanders Peirce, the founder of pragmatism and a great admirer of Reid...The point Reid is making, and which Peirce may be seen as expanding on, is that the skeptic is guilty of conflating that of being in doubt with that of possessing an unjustified belief. (Lundestad 2008: 177) ${ }^{1}$

22 As noted by Lundestad, Peirce is indeed explicit in distinguishing between real and apparent doubt. Philosophy, for Peirce (and Reid), cannot and should not pretend to proceed from systematic, yet artificial, doubt. According to Peirce, philosophy must "begin with all the prejudices which we actually have when we enter upon the study of philosophy" (Peirce 1966: 40). Reid, meanwhile, does not use the language of "prejudice," but refers to "first principles" (see, for example, Reid 1983: 151-9). It is likely for this reason that Lundestad claims that Reid, unlike the pragmatists, does not view these first principles themselves as subject to doubt at all. Lundestad articulates this ostensible difference between Reid and the pragmatists as follows:

This openness for change is of course the most striking way in which pragmatism differs from the philosophy of common sense. While Reid maintains that common sense consists of a set of beliefs which are simply to be taken for granted, or accepted as true, Dewey and the pragmatists, on the other hand, hold all knowledge to be hypothetical in character. Even our most firmly held beliefs may therefore come to be revised. (Lundestad 2006: 135)

Dewey is not the only pragmatist thinker who embraces a fallibilistic position, even with respect to the most fundamental beliefs - Peirce and James share this stance. ${ }^{2}$ It seems to me that if this difference between the pragmatists and Reid were to hold true, it would constitute an important reason to hesitate before labelling Reid a pragmatist. I believe, however, that there is reason to claim, against Lundestad, that Reid does in fact adopt a 
fallibilistic approach to knowledge of the principles of common sense that underpin his philosophical system. I shall elaborate on this in the following section.

\title{
Pragmatist Elements in Reid
}

The question as to whether Reid can fairly be labelled a pragmatist philosopher depends, of course, on one's definition of Pragmatism. That being said, I am less interested here in the terminology used to describe Reid's thought than in the degree to which it shares important features with the philosophical school known as Pragmatism. As such, it is worth noting how Pragmatism has been "defined" - not because any definition can objectively determine Pragmatism's "essential" features, but because reflection on what binds together the pragmatist philosophical tradition can help us identify, loosely, which features have been seen as constituting central elements of Pragmatism as a philosophical orientation $4 .{ }^{3}$ Perhaps the most succinct characterisation of the central features that distinguish Pragmatism has been offered by Hilary Putnam:

\begin{abstract}
What I find attractive in pragmatism is not a systematic theory in the usual sense at all. It is rather a certain group of theses, theses which can be and indeed were argued very differently by different philosophers with different concerns, and which became the basis of the philosophies of Peirce, and above all of James and Dewey. Cursorily summarized, those are (1) antiskepticism: pragmatists hold that doubt requires justification just as much as belief (recall Peirce's famous distinction between "real" and "philosophical" doubt; (2) fallibilism: pragmatists hold that there is never a metaphysical guarantee to be had that such-and-such a belief will never need revision (that one can be both fallibilistic and antiskeptical is perhaps the unique insight of American pragmatism); (3) the thesis that there is no fundamental dichotomy between "facts" and "values"; and (4) the thesis that, in a certain sense, practice is primary in philosophy. (Putman 1995: 152)
\end{abstract}

As I hope to show, I think that Putnam is wrong when he claims that the combination of anti-scepticism and fallibilisim is "unique" to the American pragmatists - Reid, too, embraced both of these postures. Furthermore, Putnam's third and fourth categories though he does not present them as essential - also seem to apply to Reid. In this section, I will examine what I believe to be six areas in which Reid's philosophy is closely aligned with positions associated with American Pragmatism. Whether or not one believes that this justifies labelling Reid himself as a pragmatist philosopher, I believe it shows his thought to bear a similarity to Pragmatism that is more comprehensive than has previously been suggested.

In the previous section, we already identified four areas of commonality, drawn out of the studies by Baumann, Magnus, and Lundestad. These are:

Reid's opposition to both Scepticism and Dogmatism.

The "argument from practical commitment."

Baumann's "Pascalian"/"Reichenbachian" reading of Reid's “broken nose" passage.

The distinction between real and apparent doubt.

In addition to these four, I suggest another two commonalities:

Fallibilism with respect to first principles.

The "rope metaphor" for reasoning (opposition to the Cartesian form of foundationalism). 


\section{Scepticism which he associates with modern philosophy in general, and with Hume in} particular. "Sensible men," Reid writes, "who never will be sceptics in matters of common life, are apt to treat with sovereign contempt everything that hath been said, or is to be said, upon this subject. Is it metaphysic, say they: who minds it? Let scholastic sophisters entangle themselves in their own cobwebs; I am resolved to take my own existence, and existence of other things, upon trust; and to believe that snow is cold, and honey sweet, whatever they may say to the contrary. He must either be a fool, or want to make a fool of me, that would reason me out of my reason and senses" (Reid 1983: 11). For Reid, common sense does not need to be justified by philosophy; rather, philosophy is dependent upon the principles of common sense. As such, "[t]o pretend to prove by reasoning that there is no force in reason, does indeed look like a philosophical delirium. It is like a man's pretending to see clearly, that he himself and all other men are blind" (Reid 2002: 563). This rejection of Scepticism resonates with the pragmatist tradition - indeed, as Putnam noted, it is an important feature of Pragmatism. One example of this approach to scepticism in the pragmatist tradition appears in the thought of James, who argues that Scepticism "is not avoidance of an option; it is option of a certain particular kind of risk" (James 1977: 732). In other words, James rejects the notion that the sceptic is choosing a 'safer' option by requiring justification before adopting any belief, since, he claims, a sceptical position necessitates justification no less.

I have already discussed commonalities (2) and (3) - namely, Reid's "argument from practical commitment" (as interpreted by Magnus); and Baumann's "Pascalian"/"Reichenbachian" interpretation of Reid's "broken nose" argument. As we saw in the previous section, the "argument from practical commitment," rather than constituting an ad hominem attack against purported sceptics who do not practise what they preach, can be understood as a more subtle, pragmatist argument, if interpreted against the backdrop of Peirce's "pragmatic maxim": "Consider what effects that might conceivably have practical bearing you conceive the object of your conception to have. Then your conception of those effects is the whole of your conception of the object" (Peirce 1966: 192). On this reading of Reid, his argument amounts to a pragmatist rejection of any distinction between Scepticism and anti-Scepticism which entails no difference in practical effects. This is reminiscent of Peirce's denial of the meaningfulness of the Catholic notion of transubstantiation in the Eucharist, on the grounds that "to talk of something as having all the sensible characters of wine, yet being in reality blood, is senseless jargon" (Peirce 1966: 124). Perhaps unsurprisingly, Peirce himself is equally sceptical about purported sceptics: "It has often been argued that absolute scepticism is self-contradictory; but this is a mistake...there are no such beings as absolute sceptics" (Peirce 1992: 56). Commonality (2) - the "argument from practical commitment" thus seems to fit with Putnam's fourth characteristic of Pragmatism, namely, the centrality of practice in philosophy.

31 Commonality (3) also gives practice prime of place in philosophy. As we saw in the previous section, Reid's "broken nose" passage can be read as arguing for the practical benefit of rejecting Scepticism. After resolving to disbelieve my senses, "I break my nose against a post that comes in my way; I step into a dirty kennel; and, after twenty such wise rational actions, I am taken up and clapped into a mad-house" (Reid 1983: 85-6). It is 
better, Reid says, to be "fooled" by nature into trusting our senses, if doing so will prevent pain and suffering that the alternative would bring about. As Baumann puts it, if the external world exists, then it is preferable, in terms of practical outcomes, not to be a sceptic; if the external world does not exist, it makes no difference whether one is a sceptic or not. A similar line of thinking appears in a number of places in Reid's writings. Thus, for example, though Reid acknowledges that the principles of common sense are open to theoretical doubt, he claims that there is nevertheless some justification for adopting them. One such reason is that "when an opinion is so necessary in the conduct of life, that, without the belief of it, a man must be led into a thousand absurdities in practice, such an opinion, when we can give no other reason for it, may safely be taken for a first principle" (Reid 1983: 265-6). These arguments bear some resemblance to the direction in which James takes Peirce's "pragmatic maxim." While for Peirce, Pragmatism is primarily concerned with discerning meaning - the practical effects of two concepts help us distinguish between them - James develops an argument in favour of utilising the pragmatic method for making decisions regarding the determination of truth. According to James, there are certain situations in which the intellect is unable to judge between beliefs, and yet a choice must be made. In such cases, a person has no choice but to consider the practical consequences of each belief and decide volitionally. ${ }^{4}$ In both James and Reid, we see here some degree of Putnam's third feature - a blurring of the distinction between "facts" and "values": I accept certain beliefs about the world because of the benefit they provide.

The last of the commonalities discussed above is (4) - the distinction between real and apparent doubt. As already noted, Lundestad points out that this distinction is implicitly present in Reid, and explicitly articulated by Peirce. Indeed, Peirce outlines his stance against feigned, philosophically-constructed doubt as follows:

We cannot begin with complete doubt. We must begin with all the prejudices which we actually have when we enter upon the study of philosophy. These prejudices are not to be dispelled by a maxim, for they are things which it does not occur to us can be questioned. Hence this initial scepticism will be a mere self-deception, and not real doubt; and no one who follows the Cartesian method will ever be satisfied until he has formally recovered all those beliefs which in form he has given up. It is, therefore, as useless a preliminary as going to the North Pole would be in order to get to Constantinople by coming down regularly upon a meridian. A person may, it is true, in the course of his studies, find reason to doubt what he began by believing; but in that case he doubts because he has a positive reason for it, and not on account of the Cartesian maxim. Let us not pretend to doubt in philosophy what we do not doubt in our hearts. (Peirce 1966: 40)

For Peirce, as for Reid, the "doubt" of Descartes or of Hume does not resemble real doubt as it is experienced in human life.

We now move on to commonalities that have not been noted previously in the secondary literature. The first of these is: (5) Fallibilism with respect to knowledge of first principles. Peirce, of course, gives expression to the extent of his fallibilistic outlook in the passage just quoted about real and apparent doubt. He states there: "A person may, it is true, in the course of his studies, find reason to doubt what he began by believing; but in that case he doubts because he has a positive reason for it, and not on account of the Cartesian maxim" (Peirce 1966: 40). In other words, Peirce regards every belief as tentative and potentially subject to revision - including those basic first principles or basic conceptions from which we proceed when entering the study of philosophy. A process that begins with particular assumptions may ultimately lead to doubting, 
altering, or rejecting those very assumptions themselves. This does not, as we saw, justify methodical doubt or Scepticism: such beliefs should be adopted confidently, even as one recognises their tentative nature - that is, the theoretical possibility that they may eventually be abandoned or adjusted.

According to both Baumann and Lundestad, Reid does not share this feature of Peirce's thought. Lundestad, as we saw, claims that Reid sees common sense as consisting of "a set of beliefs which are simply to be taken for granted, or accepted as true," while the pragmatists "hold all knowledge to be hypothetical in character." For the pragmatists but not for Reid - "even our most firmly held beliefs may therefore come to be revised" (Lundestad 2006: 135). Baumann adopts a similar position, contrasting Reid with Peirce: "In contrast [...] to Reid, Peirce allows for historical variation and critique of what common sense tells us" (Baumann 1999: 53). Neither Baumann nor Lundestad is the first to draw this distinction between Reid and the pragmatists: Peirce himself wrote that Reid "seems to think Common Sense is infallible, at least for that human-phenomenal Universe which is all there is for us. This is a great mistake. Common Sense is to be trusted only so far as it sustains critical investigation" (Peirce 1966: 426).

But does Reid really think that knowledge of the first principles of common sense is infallible? In other words: Does Reid hold that, if a given proposition is acknowledged as a first principle of common sense, this means necessarily that its truth has been accepted so conclusively that no evidence or argument could ever lead to its subsequent adjustment or rejection? I believe not. Reid has, of course, a very high level of confidence in the truth of those propositions that he identifies as first principles of common sense. This, however, is not the same as considering belief in these propositions to be infallible. Indeed, at the conclusion of a discussion in which Reid outlines the "first principles" as he understands them, he makes explicit his fallibilistic conception of them:

We do not pretend that those things that are laid down as first principles may not be examined, and that we ought not to have our ears open to what may be pleaded against their being admitted as such. Let us deal with them as an upright judge does with a witness who has a fair character. He pays a regard to the testimony of such a witness while his character is unimpeached; but, if it can be shewn that he is suborned, or that he is influenced by malice or partial favour, his testimony loses all its credit, and is justly rejected. (Reid 1983: 158-9)

Like Peirce (and James, and Dewey), then, Reid believes that we ought not force doubt where none exists, and that we can safely have a high degree of confidence in our knowledge of the propositions identified as first principles of common sense. We are to treat these propositions "as an upright judge does with a witness who has a fair character" - that is, we are to regard the burden of proof as lying with those who would challenge them, and not those who affirm them. Importantly, this confidence always remains tentative. Just as a judge's reliance upon the testimony of a "witness of fair character" is confident but provisional, so too with our affirmation of the propositions identified as first principles of common sense: These propositions are believed to be first principles, but we ought to "have our ears open to what may be pleaded against their being admitted as such." Should we be faced with a good reason to doubt that a given proposition is in fact a first principle, Reid thinks we can and should change our assessment. This seems much closer to Peirce's position than we might have thought.

Reid's fallibilistic posture is also evident in a later discussion regarding resolution of disagreement about first principles: 
But is it not possible, that men who really love truth, and are open to conviction, may differ about first principles?

I think it is possible, and that it cannot, without great want of charity, be denied to be possible.

When this happens, every man who believes that there is a real distinction between truth and error, and that the faculties which God has given us are not in their nature fallacious, must be convinced that there is a defect or a perversion of judgment on the one side or the other.

A man of candour and humility will, in such a case, very naturally suspect his own judgment, so far as to be desirous to enter into a serious examination, even of what he has long held as a first principle. He will think it not impossible, that although his heart be upright, his judgment may have been perverted, by education, by authority, by party zeal, or by some other of the common causes of error, from the influence of which neither parts nor integrity exempt the human understanding. (Reid 1983: 258) to be admitted as a first principle of common sense. In such cases, a "man of candour" might, according to Reid, "suspect his own judgment," even with respect to "what he has long held as a first principle." One must accept the possibility that one has been wrong even with respect to beliefs held so firmly as to be regarded as first principles. Only in such a manner can disputes be resolved. Reid continues:

In such a state of mind, so amiable, and so becoming every good man, has nature left him destitute of any rational means by which he may be enabled either to correct his judgment if it be wrong, or to confirm it if it be right?

I hope it is not so. I hope that, by the means which nature has furnished, controversies about first principles may be brought to an issue, and that the real lovers of truth may come to unanimity with regard to them. (Reid 1983: 258)

Though, for Reid, reason cannot be employed for resolving such disputes, he does think there are some forms of justification that can be employed in order to reach a consensus. It is telling, however, that Reid does not express conviction that all such disputes will ultimately reach unanimity; rather, he expresses this possibility in terms of hope. Not only does Reid acknowledge that firmly held convictions regarding first principles may, in certain instances, be subjected to doubt and possibly revision; he also acknowledges that unanimity (let alone absolute certainty) regarding first principles might never be achieved.

In light of these statements, it seems fair to describe Reid's approach to knowledge of first principles of common sense as a fallibilistic one. Though he may have more confidence in his belief that certain propositions are first principles than do the pragmatist philosophers, this difference would seem to be one of degree, rather than kind. Putnam's second feature of Pragmatism - fallibilism - thus also seems, in an important sense, to be present in the thought of Reid.

The last commonality I shall discuss is: (6) The "rope metaphor" for reasoning. Both Reid and Peirce reject the Cartesian form of foundationalism: that is, they do not believe that all knowledge must be derived by a series of premises from an indubitable, foundational belief. This is not to say that a certain kind of foundationalism cannot be found in Reid's writings. Indeed, Reid does claim that "all knowledge, and all science, must be built upon principles that are self-evident" (Reid 2002: 426). Later, he elaborates on this point:

When we examine, in the way of analysis, the evidence of any proposition, either we find it self-evident, or it rests upon one or more propositions that support it. The same thing may be said of the propositions that support it; and of those that 
support them, as far back as we can go. But we cannot go back in this track to infinity. Where then must this analysis stop? It is evident that it must stop only when we come to propositions, which support all that are built upon them, but are themselves supported by none, that is, to self-evident propositions. (Reid 2002: 455)

For Reid, first principles of common sense serve as "foundations" upon which other knowledge is based. This, however, is different in very important respects from the kind of foundationalism associated with Descartes, who, according to Reid, "thought one principle, expressed in one word cogito, a sufficient foundation for his whole system, and asked no more" (Reid 2002: 454). Two important differences can be noted: First, as already highlighted, Reid acknowledges the possibility of doubting a proposition previously affirmed as a first principle. Such beliefs, though held firmly, are not indubitable, and yet they nevertheless can serve as foundations for knowledge. Second, Reid - like Peirce sees great diversity and variety in the possible substance of evidence and argument, claiming that there is no single form of argument to which others can be reduced. Thus, Reid observes:

Philosophers have endeavoured, by analysing the different sorts of evidence, to find out some common nature wherein they all agree, and thereby to reduce them all to one... I am not able to find any common nature to which they may all be reduced. They seem to me to agree only in this, that they are all fitted by Nature to produce belief in the human mind, some of them in the highest degree, which we call certainty, others in various degrees according to circumstances. (Reid 1983: 200-1)

That which "produce[s] belief in the human mind" qualifies, according to Reid, as reliable evidence; there is no one specific form of argument to which others may be reduced. A very similar sentiment is articulated by Peirce in the interesting distinction he draws between an argument, which he defines as "any process of thought reasonably tending to produce a definite belief," and an argumentation, which is "an Argument proceeding upon definitely formulated premisses" 5 Arguments, for Peirce, come in a variety of radically different forms, and do not necessarily share anything more than the fact that they, to borrow Reid's words, "produce belief in the human mind."

Furthermore, Reid and Peirce both illustrate their (respective) pluralistic approaches to the diverse methods of epistemic justification by suggesting a "rope of many strands" metaphor for reasoning, as opposed to the "links in a chain" metaphor often used to characterise Cartesian foundationalism. Reid introduces this metaphor in his discussion of probable reasoning:

The strength of probable reasoning, for the most part, depends not upon any one argument, but upon many, which unite their force, and lead to the same conclusion. Any one of them by itself would be insufficient to convince; but the whole taken together may have a force that is irresistible, so that to desire more evidence would be absurd... Such evidence may be compared to a rope made up of many slender filaments twisted together. The rope has strength more than sufficient to bear the stress laid upon it, though no one of the filaments of which it is composed would be sufficient for that purpose. (Reid 2002: 556)

This description has a direct parallel in Peirce, though the latter does not quote Reid directly:

Philosophy ought to imitate the successful sciences in its methods, so far as to proceed only from tangible premisses which can be subjected to careful scrutiny, and to trust rather to the multitude and variety of its arguments than to the conclusiveness of any one. Its reasoning should not form a chain which is no stronger than its weakest link, but a cable whose fibers may be ever so slender,

European Journal of Pragmatism and American Philosophy, VI-2 | 2014 
provided they are sufficiently numerous and intimately connected. (Peirce 1966:

40-1)

features described by Putnam. Like the pragnatists, Reid is anti-sceptica; he is a falibilist features described by Putnam. Like the pragmatists, Reid is anti-sceptical; he is a fallibilist - including with respect to knowledge of first principles; he blurs the fact/ value distinction in important respects; and his approach to perception and epistemic normativity brings practice to the fore. It should be noted, of course, that this series of commonalities is not necessarily exhaustive; nor should it be taken as implying that there are no important differences between Reid and any of the American pragmatists. ${ }^{6}$ Related areas in which exploration of similarities and differences might be fruitful include: the relationship between reasoning and habit; the thinkers' respective attitudes to direct realism; ${ }^{8}$ and the influence of Charles Darwin upon the American pragmatists. ${ }^{9}$ Nevertheless, the commonalities outlined here indicate a very strong affinity between Reid's thought and the Pragmatism of Peirce, James, and Dewey.

\section{Final Words}

In the above analysis, I have shown the deep similarity between Thomas Reid and American pragmatist thinkers - in particular, Charles S. Peirce and William James. We have seen, through analysis of Baumann's, Magnus's, and Lundestad's discussions, and through investigation of the primary texts themselves, that there is a wide range of respects in which Reid's approach to epistemic justification and sense perception is very similar to those that characterise the classic American pragmatists. Indeed, Reid's philosophy possesses all of the features described by Hilary Putnam as characteristic of the pragmatist tradition. To my mind, the extent and depth of these similarities render the term "pragmatist" a useful descriptor for Reid. Nevertheless, the definitional question is not key: Rather, what is important is the very close intellectual affinity between Reid and the pragmatists upon which I have hopefully shed light.

European Journal of Pragmatism and American Philosophy, VI-2 | 2014 


\section{BIBLIOGRAPHY}

Baumann P., (1999), "The Scottish Pragmatist? The Dilemma of Common Sense and the

Pragmatist Way," Reid Studies, 2, 2, 47-57.

BAUMANN P., (2004), "On the Subtleties of Reidian Pragmatism: A Reply to Magnus," Journal of Scottish Philosophy, 2, 1, 73-7.

BERNSTEIN R., (2010), The Pragmatic Turn, Malden, Polity Press.

JAMES W., (1977), The Writings of William James: A Comprehensive Edition, ed. by J. McDermott, Chicago, University of Chicago Press.

LUNDESTAD E., (2006), "The Skeptic and the Madman: The Proto-Pragmatism of Thomas Reid," Journal of Scottish Philosophy, 4, 2, 125-37.

LUNDESTAD E., (2008), "The Necessity of Pragmatism: Overcoming the Stalemate of Common Sense," Journal of Scottish Philosophy, 6, 2, 175-87.

MAGNus P., (2004), "Reid's Dilemma and the Uses of Pragmatism," Journal of Scottish Philosophy, 2, $1,69-72$.

PEIRCE C. S., (1966), Charles S. Peirce: Selected Writings, ed. by P. Wiener, New York, Dover.

PEIRCE C. S., (1992), The Essential Peirce: Selected Philosophical Writing, Bloomington, Indiana University Press.

PUTNAM H., (1995), Words and Life, Cambridge, Harvard University Press.

PUTNAM H., (1996), “Pragmatism and Realism,” Cardozo Law Review, 18, 153-70.

REID T., (1983), Inquiry and Essays, ed. by R. Beanblossom, and K. Lehrer, Indianapolis, Hackett.

REID T., (2002), Essays on the Intellectual Powers of Man, ed. by D. Brookes, University Park, Penn State Press.

REID T., (2005), The Works of Thomas Reid, ed. by W. Hamilton, Boston, Elibron.

\section{NOTES}

1. See also Lundestad (2008: 184-5; 2006: 133).

2. See, for example, Peirce (1966: 40).

3. On the difficulty of defining Pragmatism, see Bernstein 2010. In particular, Bernstein writes: "It is best to think of the discourse about pragmatism as an open-ended conversation with many loose ends and tangents. I don't mean an 'idealized' conversation or dialogue, so frequently described and praised by philosophers. Rather, it is a conversation more like the type that occurs at New York dinner parties where there are misunderstandings, speaking at cross-purposes, conflicts, and contradictions, with personalized voices stressing different points of view (and sometimes talking at the same time). It can seem chaotic, yet somehow the entire conversation is more vital and illuminating than any of the individual voices demanding to be heard. This is what the conversation of pragmatism has been like" (Bernstein 2010: 30-1). 
4. In "The Will to Believe," James writes: "Our passional nature not only lawfully may, but must, decide an option between propositions, whenever it is a genuine option that cannot by its nature be decided on intellectual grounds; for to say, under such circumstances, 'Do not decide, but leave the question open', is itself a passional decision - just like deciding yes or no - and is attended with the same risk of losing the truth" (James 1977: 723; italics in original).

5. This distinction appears in Peirce's “A Neglected Argument for the Reality of God" (1966: 359).

6. Of course, the differences between the American pragmatists themselves are significant. Such disagreements eventually led Peirce to adopt an alternative term - "pragmaticism" - to describe his own thought and distinguish it from others (including James) who had come to be described as pragmatists. See Peirce (1966: 186).

7. See, for example, Reid (2002: 543); Peirce (1966: 91-112).

8. Reid (1983: 272-3). Some have characterized Pragmatism as anti-realist. Putnam, however, views James and Peirce as direct realists (Putnam 1996). 10. See Lundestad (2006: 133-6).

9. See Lundestad (2006: 133-6).

\section{ABSTRACTS}

The intellectual affinity between Thomas Reid, on one hand, and American pragmatists such as Charles Sanders Peirce, William James, and John Dewey, on the other, has been noted by several scholars. Indeed, Peirce himself professed an admiration for Reid and referred to his own Pragmatism as entailing what he called "Critical Common-sensism." In recent times, a number of scholars - chiefly Baumann, Magnus, and Lundestad - have investigated the pragmatist elements in Reid's thought. Each has identified important ways in which Reid prefigured central themes in American pragmatist thought, though none has gone so far as to label Reid himself a pragmatist. In this paper, I demonstrate the great extent of the similarities between Reid and some of the early American pragmatists. In light of these affinities, the term "pragmatist" may, in my opinion, be helpful for categorising Reid's thought. My central claim, however, is not merely a terminological one: Rather, I attempt to demonstrate the deep and broad intellectual affinity between Reid's “Common Sense" philosophy and major trends in American Pragmatism, by shedding light on a number of distinct and central shared features.

\section{AUTHOR}

\section{ADRIAN SACKSON}

New York University

asackson[at]nyu.edu 